\title{
Assessment of Arbuscular Mycorrhizal Association in Some Fruit Plants in Bangladesh
}

\author{
Delowara Khanam* \\ Soil Science Division, Bangladesh Agricultural Research Institute (BARI), Joydebpur, Gazipur 1701, Bangladesh
}

[Received 01 March 2007; Accepted 21 April 2007]

\begin{abstract}
Rhizosphere soils of $\mathbf{1 9}$ fruit plants from horticultural farm of Bangladesh Agricultural Research Institute (BARI), Joydebpur, Gazipur were assessed for arbuscular mycorrhiza (AM) spore population and determining colonization in their roots. The spore numbers recorded ranged from 48.0 (Citrus limon) to 1,050 (Annona reticulata) per $100 \mathrm{~g}$ soil in 2004, 41.0 (Citrus grandis) to 916.7 (Phyllanthus emblica) in 2005 and 44.3 (Citrus grandis) to 575.0 (Syzygium samarangense, white) in 2006. A considerable variation was observed in average spore numbers recorded in three consecutive years. Different fruit plants showed different percentages of root colonization by AM fungi. Among all the fruit plants, the highest colonization (86.7\%) was found in Syzygium jambos and Elaeocarpus floribundus and the lowest colonization (20.0\%) was recorded in Syzygium samarangense (red).
\end{abstract}

Keywords: Arbuscular mycorrhiza (AM), Colonization, Spore population, Fruit plants

\section{Introduction}

Mycorrhizae are symbiotic association between beneficial soil fungi and plant roots. They have an important role in increasing plant uptake of $\mathrm{P}$ and other poorly mobile micronutrients particularly $\mathrm{Zn}$ and $\mathrm{Cu}^{1}$. Out of the different types of mycorrhizae, the arbuscular mycorrhiza (AM) fungi are the most widely occurring mycorrhizae and are very important in relation to the improvement of agricultural and horticultural crops and forest trees in hilly areas ${ }^{2}$. They form three-way associations involving plants, fungi and soils. Wide diversity exists within the group of fungi responsible for the formation of AM by most plants in the majority of terrestrial ecosystems. The selection of the most specific appropriate plant-fungus association for each specific environmental and ecological situation is one of the main challenges in current research on AM. Therefore, knowledge of the different factors influencing the population biology of AM fungi is essential in any attempt to use them in environmental conservation $^{3}$, biotechnology ${ }^{4}$ or in sustainable agriculture ${ }^{5}$.

The identification of indigenous AM fungi is a fundamental requirement to understand biodiversity and essential for monitoring changes in natural, managed or disturbed ecosystems. Diversity in AM fungi can be explored at this level by studying spore characteristics, ultra-structural features and infection patterns in different agricultural crops including different varieties of the same crop. The AM fungi are abundant and ecologically very important in the tropics ${ }^{6}$ and have been recognized as a promising alternative technology for reducing fertilizer requirement of the major crop species ${ }^{6-7}$. Soils in the tropics are either poor in phosphorus (P) and other essential nutrients or have an immobile form of $\mathrm{P}^{8}$. Hence AM fungal inoculum could be added to the soil for better uptake of $\mathrm{P}$ to enhance crop production in tropical countries. Bangladesh produces a variety of fruits.

It seems that there is an important role of arbuscular mycorrhizal fungi in nutrient availability for these fruit plants. But still no work has been done to assess the mycorrhizal association with different fruit plants. So, this present work was taken to know the percent root colonization of fruit plants and the number of AM spores in the rhizosphere soils for producing suitable inoculum for future use in different fruit crops.

\section{Materials and Methods}

Nineteen fruit plants from Horticultural farm of Bangladesh Agricultural Research Institute (BARI), Joydebpur, Gazipur were selected for the assessment of arbuscular mycorrhizal association. Rhizosphere soils were collected in three consecutive years (20042006) from the same plants and places. Assessment of spore population was done by following the wet sieving and decanting method $^{9}$. Spores were observed under stereomicroscope and the number of spores was counted. Spore numbers from the three replicates per sample were averaged and the result was expressed as number per $100 \mathrm{~g}$ of dry soil basis.

The root pieces of each plant species were stained according to Koske and $\mathrm{Gemma}^{10}$. The root pieces were boiled in $2.5 \% \mathrm{KOH}$ solution for $30 \mathrm{~min}$ at $90^{\circ} \mathrm{C}$. Then, the root segments were washed in water several times and acidified with $1 \% \mathrm{HCl}$ solution for $24 \mathrm{~h}$.

*Corresponding author:

Dr. Delowara Khanam, Principal Scientific Officer, Soil Science Division, Bangladesh Agricultural Research Institute (BARI), Joydebpur, Gazipur 1701, Bangladesh Tel (Office): (02) 9252893; Cell: 01711 958483; E-mail: dkhanam54@yahoo.com 
Heavily pigmented roots were bleached in $10 \% \mathrm{H}_{2} \mathrm{O}_{2}$ for 20 to 60 $\mathrm{min}$. Again these segments were boiled for $30 \mathrm{~min}$ in $0.05 \%$ aniline blue at a temperature of $90^{\circ} \mathrm{C}$. Subsequently, the stained roots were destained at room temperature using acidic glycerol.

Root colonization (\%) of arbuscular mycorrhiza (AM) was estimated by root slide technique ${ }^{11}$. One hundred root segments were examined for each sample. The stained root pieces were mounted in acidic glycerol on slides covered with cover slips that were slightly pressed. The stained roots were observed under a microscope. A root segment was considered as positively infected, if it showed mycelium, vesicles and arbuscules, or any other combination of these structural characteristics of AM colonization. The presence or absence of colonization in the root pieces was recorded and the percent of root colonization was calculated as follows:

Root colonization $(\%)=\frac{\text { No. of AM positive segments }}{\text { Total No. of segments scored }} \times 100$

Physical and chemical properties were determined of a composite soil sample following ASI method ${ }^{12}$.

\section{Results and Discussion}

Association between arbuscular mycorrhiza (AM) fungi and root of agricultural or horticultural plants is very important ${ }^{2}$. In this study, a horticultural farm of BARI, Gazipur was selected for the assessment of arbuscular mycorrhizal association with some fruit plants. The physicochemical properties of the farm are summarized in Table 1.

Table 1. Physical and chemical properties of soil of horticultural farm

\begin{tabular}{lcc}
\hline Soil variable & Content & Critical level \\
\hline $\mathrm{pH}$ & 5.7 & - \\
Organic matter (\%) & 2.34 & - \\
Total N (\%) & 0.124 & - \\
Available P (ppm) & 73 & 14 \\
Available S (ppm) & 35 & 14 \\
Exchangeable K (meq/100ml) & 0.32 & 0.2 \\
Exchangeable Ca (meq/100ml) & 4.1 & 2 \\
Exchangeable Mg (meq/100ml) & 1.3 & 0.8 \\
Available Zn (ppm) & 2.4 & 2 \\
Available Cu (ppm) & 2.9 & 1 \\
Available Fe (ppm) & 427 & 10 \\
Available Mn (ppm) & 40 & 5 \\
\hline
\end{tabular}

Spore population of arbuscular mycorrhiza (AM) in the rhizosphere of some fruit plants was assessed in three consecutive years. A considerable variation was observed in average spore number recorded in three consecutive years (Figure 1). The average spore numbers per $100 \mathrm{~g}$ soil of three years were $397.7 \mathrm{in}$ the year 2004, 321.3 in the year 2005 and 139.5 in the year 2006. The spore density decreased abruptly in 2006 as compared to that in the year 2004 and 2005. This change might be due to climatic variation from year to year that also led to the changes of some edaphic factors critical for distribution and abundance of AM fungi ${ }^{13-15}$.

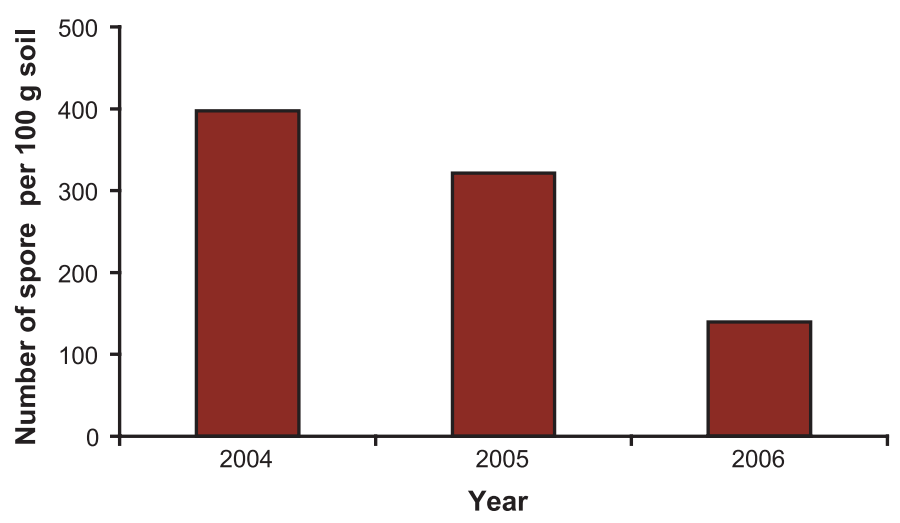

Figure 1. Variation of number of arbuscular mycorrhiza (AM) spores in the rhizosphere soils of different fruit plants in three consecutive years.

Table 2 shows the spore numbers associated with rhizosphere soils of different fruit plants. The spore counts of 8 plants were high (>100/g soil) in the three consecutive years. These included Annona reticulata, Averrhoa carambola, Carissa congesta, Litchi chinensis, Manilkara zapota, Spondias mangifera, Syzygium jambos and Syzygium samarangense (white). Very high ( $>500 / \mathrm{g}$ soil) count was observed in the rhizosphere soil of Annona reticulata, Averrhoa carambola, Phyllanthus emblica, Psidium guajava and Zizyphus mauritiana in the year 2004, Mangifera indica, Phyllanthus emblica, Syzygium jambos and Syzygium samarangense (white) in the year 2005, and Syzygium samarangense (white) in the year 2006. The counts were low $(<100 / \mathrm{g}$ soil) in the three consecutive years in case of Citrus grandis and Syzygium samarangense (red).

In present study, the spore density in the rhizosphere soil varied in different fruit plants, which was supported by Howeler et al. ${ }^{16}$ who reported that the intensity of spore density varied on different factors like plant species and genera and nature of rhizosphere soil. Moreover, higher spore population was observed in some fruit plants. The stimulating effects of organic matter, comparatively high level of $\mathrm{N}$ and $\mathrm{P}$ might have created a favourable condition for maximum sporulation of AM fungi in that particular field.

Table 3 represents the percent root colonization of different fruit plants. Different fruit plants showed different degrees of root colonization by AM fungi. The percent root colonization varied from 16.7 to $86.7 \%$. More than $50 \%$ colonization was recorded with Carissa congesta, Citrus grandis, Diospyros discolor, Elaeocarpus floribundus, Litchi chinensis, Psidium guajava, Spondias mangifera, Syzygium jambos, Tamarindus indica and Zizyphus mauritiana. Among all the fruit plants, the highest colonization (86.7\%) was found in Elaeocarpus floribundus and Syzygium jambos. The lowest colonization (16.7\%) was recorded in white Carissa congesta. The variation observed in the colonization of AM fungi among different fruit plants might be due to the differences in the structure of root system, phosphorus uptake $^{17}$ and also might be genetical variations ${ }^{18}$. 
Table 2. Spore population of arbuscular mycorrhizae in rhizosphere soil of different fruit plants during 20042006

\begin{tabular}{lccc}
\hline Fruit plant & \multicolumn{3}{c}{ Spore number per 100 g soil $^{\mathrm{a}}$} \\
\cline { 2 - 4 } (Local name / English name) & 2004 & 2005 & 2006 \\
\hline Annona reticulata (Ata / Bullock’s heart) & $1,050.0 \pm 50.0$ & $270.0 \pm 15.3$ & $105.3 \pm 7.5$ \\
Artocarpus heterophyllus (Kathal / Jackfruit) & $448.0 \pm 68.0$ & $270.0 \pm 15.3$ & $89.3 \pm 8.7$ \\
Averrhoa carambola (Kamranga / Carambola) & $527.0 \pm 25.0$ & $306.7 \pm 23.3$ & $127.7 \pm 14.7$ \\
Carissa congesta (Karomcha / Bengal currant) & $483.0 \pm 7.3$ & $225.0 \pm 14.4$ & $220.0 \pm 16.1$ \\
Citrus grandis (Batabi lebu / Shaddock) & $62.0 \pm 13.0$ & $41.7 \pm 6.0$ & $44.3 \pm 3.5$ \\
Citrus limon (Lebu / Lemon) & $48.0 \pm 18.0$ & $116.7 \pm 20.3$ & $53.3 \pm 3.5$ \\
Diospyros discolor (Bilati gab / Velvet apple) & $55.0 \pm 5.0$ & $270.0 \pm 15.3$ & $62.0 \pm 7.2$ \\
Elaeocarpus floribundus (Jalpai / Indian olive) & $163.0 \pm 47.0$ & $85.0 \pm 10.4$ & $194.0 \pm 8.3$ \\
Litchi chinensis (Lichu / Litchi) & $480.0 \pm 72.0$ & $433.0 \pm 44.1$ & $271.7 \pm 14.8$ \\
Mangifera indica (Aam / Mango) & $102.0 \pm 18.0$ & $697.3 \pm 57.8$ & $53.3 \pm 3.5$ \\
Manilkara zapota (Shafata / Sapota) & $177.0 \pm 25.0$ & $295.0 \pm 13.2$ & $96.7 \pm 8.8$ \\
Phyllanthus emblica (Amloki / Aonla) & $950.0 \pm 50.0$ & $916.7 \pm 44.1$ & $66.7 \pm 6.0$ \\
Psidium guajava (Payara / Guava) & $787.0 \pm 13.0$ & $83.3 \pm 16.9$ & $89.0 \pm 6.7$ \\
Spondias mangifera (Amra / Hog plum) & $250.0 \pm 50.0$ & $225.0 \pm 14.4$ & $105.3 \pm 7.5$ \\
Syzygium jambos (Golapjam / Rose apple) & $185.0 \pm 7.6$ & $856.7 \pm 34.8$ & $169.0 \pm 9.7$ \\
Syzygium samarangense (Jamrul / Wax jambu, red) & $74.0 \pm 7.0$ & $91.7 \pm 6.0$ & $54.0 \pm 4.6$ \\
Syzygium samarangense (Jamrul / Wax jambu, white) & $497.0 \pm 25.0$ & $650.0 \pm 32.2$ & $575.0 \pm 13.2$ \\
Tamarindus indica (Tetul / Tamarind) & $467.0 \pm 35.0$ & $191.7 \pm 6.0$ & $86.3 \pm 8.8$ \\
Zizyphus mauritiana (Deshi kul / Jujube & $752.0 \pm 48.0$ & $80.0 \pm 2.9$ & $188.3 \pm 6.0$ \\
\hline
\end{tabular}

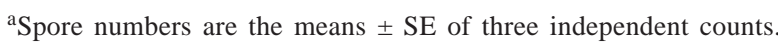

Table 3. Root colonization (\%) of arbuscular mycorrhiza (AM) fungi in different fruit plants

\begin{tabular}{|c|c|c|c|c|c|}
\hline \multirow{2}{*}{$\begin{array}{l}\text { Fruit plant } \\
\text { (Local name / English name) }\end{array}$} & \multirow{2}{*}{$\begin{array}{c}\text { Root } \\
\text { colonization (\%) }\end{array}$} & \multicolumn{4}{|c|}{ AM structure } \\
\hline & & Нурае & Arbuscle & Vesicle & Vesicle shape \\
\hline Annona reticulata (Ata / Bullock’s heart) & $40.0 \pm 5.8$ & + & + & - & - \\
\hline Artocarpus heterophyllus (Kathal / Jackfruit) & $56.7 \pm 3.3$ & + & - & - & - \\
\hline Averrhoa carambola (Kamranga / Carambola) & $16.7 \pm 3.3$ & + & - & - & - \\
\hline Carissa congesta (Karomcha / Bengal currant) & $66.7 \pm 3.3$ & + & + & - & - \\
\hline Citrus grandis (Batabi Lebu / Shaddock) & $76.7 \pm 3.3$ & + & + & + & Spherical \\
\hline Citrus limon (Lebu / Lemon) & $23.3 \pm 3.3$ & + & - & - & - \\
\hline Diospyros discolor (Bilati gab / Velvet apple) & $60.0 \pm 5.8$ & + & - & + & Oval \\
\hline Elaeocarpus floribundus (Jalpai / Indian olive) & $86.7 \pm 3.3$ & - & + & + & Oval \\
\hline Litchi chinensis (Lichu / Litchi) & $60.0 \pm 5.8$ & + & + & - & - \\
\hline Mangifera indica (Aam / Mango) & $30.0 \pm 5.8$ & + & - & - & - \\
\hline Manilkara zapota (Shafata / Sapota) & $43.3 \pm 3.3$ & + & - & - & - \\
\hline Phyllanthus emblica (Amloki / Aonla) & $40.0 \pm 5.8$ & + & - & - & - \\
\hline Psidium guajava (Payara / Guava) & $26.7 \pm 3.3$ & + & - & - & - \\
\hline Spondias mangifera (Amra / Hog plum) & $66.7 \pm 3.3$ & + & + & + & Spherical \\
\hline Syzygium jambos (Golapjam / Rose apple) & $86.7 \pm 3.3$ & + & - & - & Oval \\
\hline Syzygium samarangense (Jamrul / Wax jambu, red) & $30.0 \pm 5.8$ & + & - & - & - \\
\hline Syzygium samarangense (Jamrul / Wax jambu, white) & $20.0 \pm 5.8$ & + & - & - & - \\
\hline Tamarindus indica (Tetul / Tamarind) & $73.3 \pm 3.3$ & - & + & + & Oval \\
\hline Zizyphus mauritiana (Deshi kul / Jujube & $60.0 \pm 5.8$ & - & + & + & Spherical \\
\hline
\end{tabular}

aPercent root colonization are the means \pm SE of three independent counts. 
The AM fungal structure in the root system of the selected fruit plants varied irrespective of fruit species (Table 3). Out of 19 plants only 7 had vesicles. Hyphae were not present in Elaeocarpus floribundus, Syzygium jambos, Tamarindus indica and Zizyphus mauritiana. Arbuscules were found in 9 plants. Both oval and spherical vesicles were found in this study, which was supported, by Muthukumar et al. ${ }^{13}$ and Khanam et al. ${ }^{14-15}$.

Spore number and root colonization varied from plant to plant in the present study. But variations in spore numbers in different plants were not related to per cent root colonization which is in agreement with Khalil et al. ${ }^{19}$. As a wide range of host, fungal and environmental factors are known to influence AM formation and subsequent spore production; these two phenomena may not necessarily be related.

\section{References}

1. O’Keefe DM \& Sylvia DM. 1991. Mechanisms of the vesicular arbuscular mycorrhizal plant growth response. In Handbook of Applied Mycology (Arora DK ed), pp 35-54. Marcel Dekker, New York.

2. Mridha MAU \& Xu HL. 2001. Nature farming with vesicular arbuscular mycorrhizae in Bangladesh. J Crop Prod. 3: 303-312.

3. Allen MF. 1991. The Ecology of Mycorrhizae. Cambridge University Press, Cambridge.

4. Mulongoy K, Gianinazzi S, Roger PA \& Dommergues Y. 1992. Biofertilizers: Agronomic and environmental impacts and economics. In Biotechnology, Economic and Social Aspects: Issues for Developing Countries (Da Silva EG, Rutledge C \& Sasson A eds), pp 55-69. UNESCO, Cambridge University Press, Cambridge.

5. Bethlenfalvay GJ \& Linderman RG. 1992. Mycorrhizae in sustainable Agriculture. Special Publication No. 54. American Society of Agronomy, Medison.

6. Mosse B. 1981. Vesicular-arbuscular mycorrhizal research in tropical agriculture. Research Bulletin 194, p 82. Hawaii Institute of Tropical Agriculture and Human Resource, University of Hawaii, Honolulu, Hawaii.
7. Yost RS \& Fox RL. 1979. Contribution of mycorrhizae to P nutrition of crops growing on an oxisol. Agron J. 71: 903-908.

8. Menge JA. 1983. Utilization of vesicular arbuscular mycorrhizal fungi in agriculture. Can J Bot. 61: 1015-1024.

9. Gerdemann JW \& Nicolson TH. 1963. Species of mycorrhizal endogone species extracted from soil by wet sieving and decanting method. Trans Brit Mycol Soc. 46: 235-246.

10. Koske RE \& Gemma JN. 1989. A modified procedure for staining roots to detect VA mycorrhizas. Mycol Res. 92: 486-488.

11. Read DJ, Koucheki HK \& Hodgaon J. 1976. Vesicular arbuscular mycorrhiza in natural vegetation systems. New Phytol. 77 : 641-653.

12. Hunter AH. 1984. Soil fertility analytical service in Bangladesh. Consultancy Report. Bangladesh Agricultural Research Council (BARC), Dhaka.

13. Muthukumar T, Udaiyan K \& Manian S. 1994. Role of edaphic factors on VAM fungal colonization and spore populations in certain tropical wild legumes. Pertanika. J Trop Agric Sci. 17: 33-42.

14. Khanam D, Solaiman ARM, Mridha MAU \& Karim SAJM. 2003. Arbuscular mycorrhizal fungi association with some agricultural crops grown in four agro-ecological zones of Bangladesh. Bangladesh $J$ Soil Sci. 27-28: 1-12.

15. Khanam D, Solaiman ARM \& Mridha MAU. 2004. Biodiversity of arbuscular mycorrhizal fungi in agricultural crops grown under different agro-ecological zones of Bangladesh. Bull Inst Trop Agric Kyushu Univ. 27: 25-33.

16. Howeler RH, Seiverding E \& Saif S. 1987. Practical aspects of mycorrhizal technology in some tropical crops and pastures. Plant Soil. 100 : 249-283.

17. Hetrick BAD, Wilson GWT \& Todd TC. 1992. Relationship of mycorrhizal symbiosis, rooting strategy, and phenology among tallgrass prairie forbs. Can J Bot. 70: 1521-1528.

18. Mercy MA, Shivashankar G \& Bagyaraj DJ. 1990. Mycorrhizal colonization in cowpea is host dependent and heritable. Plant Soil. 121: 292-294.

19. Khalil S, Loynachan TE \& McNabb HS. 1992. Colonization of soybean by mycorrhizal fungi and spore population in Iowa soils. Agron J. 84: 832-836. 